\title{
XLII. Description of a hydro-pneumatic table for collecting and transferring gases, and for experimenting on permanently elastic fluids
}

\section{Fredrick Accum M.R.I.A. F.L.S.}

To cite this article: Fredrick Accum M.R.I.A. F.L.S. (1810) XLII. Description of a hydro-pneumatic table for collecting and transferring gases, and for experimenting on permanently elastic fluids, Philosophical Magazine Series 1, 35:144, 247-251, DOI: 10.1080/14786441008563077

To link to this article: http://dx.doi.org/10.1080/14786441008563077

曲 Published online: 18 May 2009.

Submit your article to this journal $\pi$

ЏII Article views: 2

Q View related articles $₫$ 
he says, "In hoc autem opusculo nullus erit fictioni locus, eam si excipias, quæ ad lacum Mexicanum canentes poetas inducit. Quæ vidi refero, quæque mihi testes oculati, cæteroquin veracissimi, retulere. Præterea curæ mihi fuit oculatorum testium auctoritate subscripta, quæ rariora sunt, confirmare." I ain, sir, with much respect,

Philadelphia, Nov. 1, 1809.

$$
\text { Your obedient servant, \&c., }
$$

Benjamin Smith Barton.

XLII. Description of a Hydro-pneumatic Talle for collecting aud transferring Gases, and for experimenting on permanently elastic Fluids. By Fradnick Accum, Operative Chemist, Lecturer on Chemistry and on Mineralogy and Pharmacy, M.R.I.A., F.L.S., \&ீc.*

$\mathrm{T}$

HERE is but one sure road to arrive at truth in all departments of experimental knowledge, namely, to consult nature herself by operative experiment; and this becomes the more necessary as the subjects to be studied are more complicated and extended.

In mathematics, the propositions necessary to be known for the acquisition of knowledge, are self-evident, and admiitted as soon as announced, and from their ready admission the student is led to the explanation of the most complicated truth. In the system of chemical science it is otherwise. This branch of inquiry, it may be said, opens with a detail of various processes which are by no means self-evident, nor easily to be repeated by those who have not yet a claim to the title of a chemist.

'Io awaken the ardour of chemical research, as well as to give facility to the practical acquisition of knowledge at the least possible cost, and in the most advantageous manner, must therefore be an object of some importance to the advancement of science; for to the abridgement of labour, and the superior aid of modern instruments of research, does the science of chemistry owe its rapid strides towards perfection.

It is well known that before the invention of the thermometer, men were accustomed to judge of the different degrees of heat and cold, by the sensations produced on their organs of feeling, and the estimates must have been ofien highly exaggerated, and always vague and fallacious. It must be acknowledged that a number of valuable facts

* Communicated by Mr. Accum.

Q4 would 
would still be wanting, chiefly with regard to our knowledge of the constitution of mineral bodies, if Bergman had not pointed out the effects of the blowpipe, an instrument of the greatest value to the mineralngical chemist.

What a deal of trouble and expense, as well as time; (that most inestimable of all the desiderata of experimental research,) is saved by the form which Nicholson has given to the gravimeter, an instrument which renders the modes of ascertaining the specific gravities of solids and fluids, at once easy, expeditious, and accurate, to the fifth figure of the decimal, water being taken as unity*.

What a vast field of inquiry has been opened to the chemical philosopher by the very simple modification of the air-thermometer of Leslie, - an instrument of uncommon delicacy, employed by him with the greatest advantage in his important researches concerning the mensuration of the force and density of light! and with what ease, expedition and ceconomy are at present performed (even in the closet) those operations which in former times demanded a regular latoratory! The moveable furnace of Dr. Black $t$, the blast furnace of Aikin, and the lamp furnace of Guiton, are now considered as sufficient for carrying on, in the small way, all those operations of the science, in which either a very intense or a very low heat is necessary. These apparatus alone, it may be said, have banished from the laboratory a number of unwieldy and costly contrivances, which served only to excite enbarrassment and confusion. Many tedious processes in the practice of our science have thus been made easy by the help of modern instruments, hazardous ones are become safe, expensive ones cheap, and the means of experimenting have been brought to every door, The cultivators of chemical science who have no access to the laboratury of the operative chemist, are too well acquainted

- It does not appear that any better instrument for finding specific gravities for the use of the chemist need be wished for. The gravimeter of Nicholson is susceptible of correction for the variation of temperature, and the impurity of the water in which it is to be immersed, which for practice is sometimes more convenient. It requirea no address in using it, and the price at which the instrument may be purchased is far below that of the most ordinary kind of hydrostatic balance.

+ This furnace has been considerably improved by others, since it first intrculuction into practice. It is vẹry substantial, durable, not liable to be easily injured by external blows, and capable of producing a degree of heat more than sulficient to melt iron. It is perfectly safe in a room; and the thickness of the walls, composed of fire bricks, with which it is lined, prevents the operator from being molested by the heat when the furnace is in action. See * Manual of Analytical Mineralogy, intended to facilitate the practical Analysis of Minerals," by F. Accum, 2d edit. page 38. 
with the utility of the instruments before named, to render any further observations concerning them necessary.

It is in consequence of such reflections, and the invitations I have received from others, whose judgement I respect, that I take the freedom to lay before the public the annexed sketch of a pneumatic table, which in the routine of my profession I have found extremely useful in operating on yases, which I flatter myself will be found an acquisition among the apparatus to the laboratoty.

The discovery of the gases, and their great importance in the researches of modern chemistry, have occasioned, as is well known, the necessity of some peculiar instruments, by means of which these bodies may be caught, collected, transferred, and submitted to the action of other bodies. Among these the very simple and ingenious reservoir, invented by Dr. Priestley, and named by him the pneumatic trough, is the most indispensable. Several alterations have been proposed in the structure of this vessel, to render it more convenient for use; but these, it may be said, relate either to its form only, or to its neatness and general appearance and not to its principles, or application and utility, as connected with the operations of pneumatic chemistry.

Fig. 1. (Plate VII.) represents a wooden table three feet six inches high, two feet ten inches long, and one foot eight inches broad. At each end of this table, and at a depth of ten inches from its upper edge, is a moveable braard or platform $d d$ measuring 18 inches by $16 \frac{1}{2}$. These platforms are supported horizontally by swing-brackets $e \in$, which may be turned aside to allow the platiorns $d d$ to fall down between the inner sides of the legs of the tible. The brackets $e e$ are then concealed from view. The platforms $d d$ serve to support table furnaces, retorts, and stands, or other apparatus employed in the production of gases. Fig. 2. is an ceconomical lamp furnace with its retort in action, to show the use of the platforms. The upper part of the pneumatic table is surrounded by a broad rim or border $x x$ two inches and a half deep, so as to form a shallow tray. It is of rather larger dimensions than the table, projecting over the frame of it about three fourths of an inch. This tray (as I shall call it) is divided into two unequal compartments, namely, a cistern $a$ a occupying one end or side, and a stage or shallow plain $b$ occupying the other. The cistern $a a$ is 16 inches deep, 19 wide, and 16 broad; the stage or plain $b$ occupies the remaining part of the tray $b$. When the table is intended to 


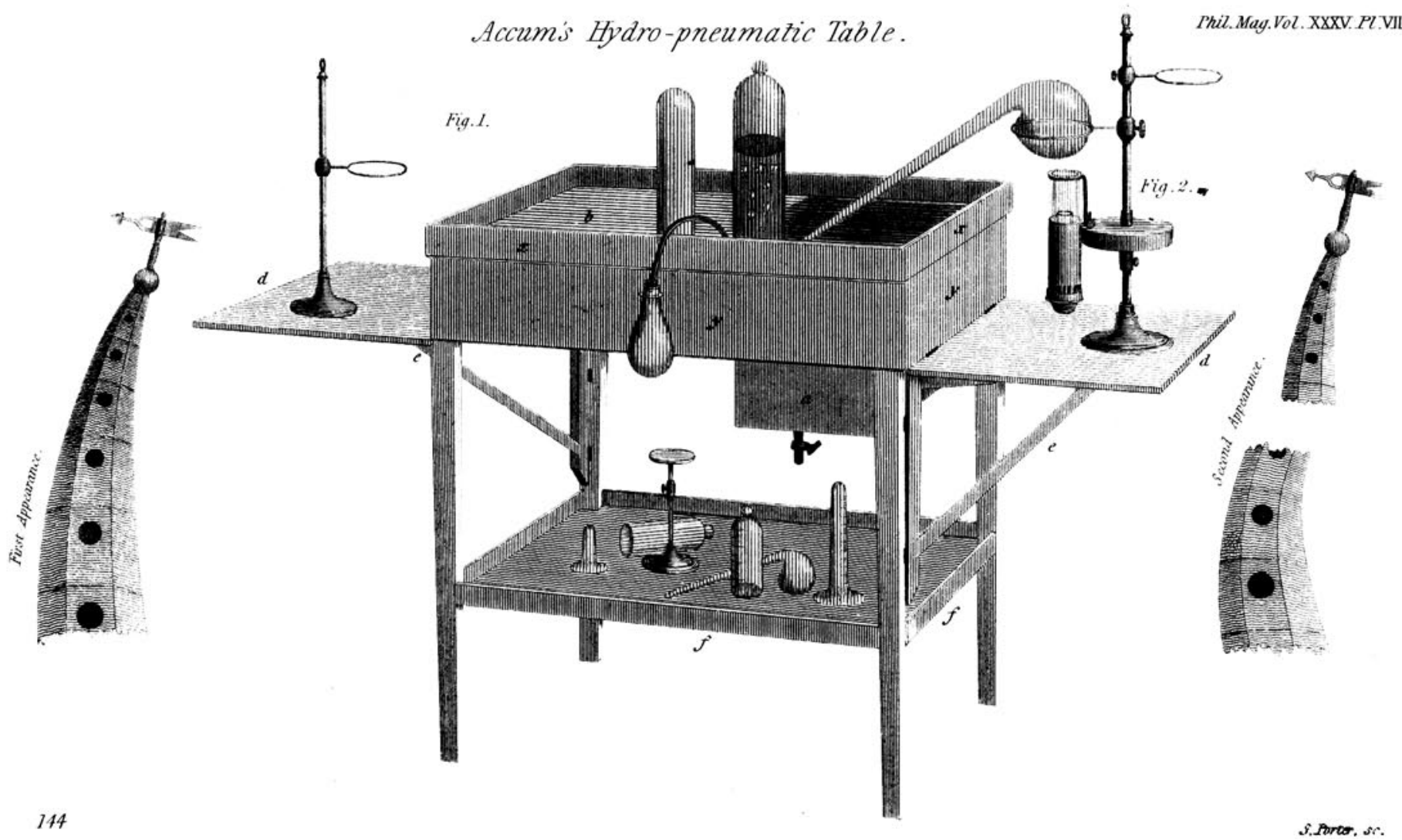


be used, the tray $x x x$, together with its cistern $a a$, and stage or plain $b$, is to be filled with water, so as to stand at least three fourths of an inch deep over the shallow plain or stage $b$ in every direction. Across the cistern $a \boldsymbol{a}$ is a shelf, marked $c$ in the drawing; it is five inches broad, and perfectly level with the stage $b$. This shelf slides backwards and forwards horizontally within the cistern $a$, so that it may be placed at any convenient $\mathrm{di}$ stance from the lamp furnace, fig., 2 , or other vessel from which gas proceerls. It is provided on its foremost edge with a row of holes, into which from underneath, broad short-necked funnels are fixed; it serves to support the receivers standing on the shelf $c$, with their open ends turned downwards upon the betore-mentioned holes, through which afterwards the gas conveyed by the funucls is made to pass into the jars destined to receive it. As this shelf is level with the stage, and may, by its sliding motion, be brought close to the stage $b$ where it terminates in the cistern, the jars placed upon this shelf, when filled with gas, may be slided along without further trouble to a distant part on the adjoining plain $b$, whilst other vessels previously filled with water in the cistern $a \boldsymbol{a}$, and standing also on the plain $b$, may in return instantly be moved on the shelf $c$; and thus the trouble of removing the jars into and out of the cistern is totally avoided.

From this statement it will be seen that the advantages of the pneumatic table are considerable. It enables the operator to fill jars or vessels with the utmost neatness, convenience and expedition. The necessity of transferring them when filled with gas, out of the trough, is avoided, and the danger of suffering part of the gas to escape, as well as the almost unavoidable spilling of water whilst the vessels are removed, is completely guarded against. It enables the operator also to fill jars of almost any size, which cannot be done in the common trough, without rendering it unwieldy and very cumbersome, or without being at least obliged to immerse the jars previously into a deeper trough, and thence conveying them upon a plate or saucer into the reservoir in which they are to be filled with gas. Thus the constant danger of having either too much water, so as to overflow the trough, or too little, so as to admit common air to enter into the jars when the water sinks below the shelf, is effectually remedied. In the common trough the vessels are alse exceedingly liable to be overset by the pressure of the 
water, the height of which rapidly increases when large jars are filled, and require continual removing.

When large quantities of gases are required, as in public lectures, this pneumatic table has been found exceedingly useful. The operator not being restrained for room in the management of his experiments, nor being obliged to transfer the vessels continually in and out of the apparatus, and being enabled to perform his operations within a confined space and without encroaching upon any surrounding furniture, are likewise no small advantages, which entitle it to the attention of those who have no access to the laboratory of the operative chemist. The shelf $f f$ is very serviceable as a receptacle for holding whatever utensils may be deemed necessary to be near at hand during the experiment.

Compton Street, Soho, March 12, 1810. Fredrick Accum.

XLIII. On Salmon-Fry: in Answer to a Correspondent whose Communication appeared in our last Number. By John Carr, Esq., of Manchester*.

To Mr. Tilloch.

Sir, $A_{\text {r.mberal discussion of subjects in British natural }}$ history certainly affords a very amusing variety amongst the more abstruse branches of scientific research, which obtain so deserved a preference in your select journal; and it is with this view that I submit my present observations, rather than from a wish to attain any triumph over the brief and illusory remarks on Salmon-leaps, in your Magazine for last month. What I formerly stated, and shall now offer, is the result of my own personal observations in the Tweed, Coquet, Tyne, Eden, Esk, and several other northern rivers which swarm with salmon, and I mention this only as increasing the responsibility for what I shall advance.

Were it really a fact, as contended for by the writer I am opposing, that salmon-fry actually continue upwards of twelve months in the same river where they are spawned; then during the summer months, (when the streams are

- Mr. Carr is respectfully informed that, if we have not misunderstood his allusion, he is mistaken respecting the author of the paper to which he has sent this $2 s$ an answer. We have therefore suppressed his introductory paragraph-EDiT. 